\title{
新規な複合糖質糖鎖迅速合成法の開発
}

\author{
眞 鍋史乃
}

\section{Development of Novel Methodology for Rapid Conjugated Oligosaccharide Synthesis}

\author{
Shino MANABE \\ RIKEN (The Institute of Physical and Chemical Research), Hirosawa, \\ Wako City, Saitama 351-0198, Japan
}

(Received January 30, 2002)

\begin{abstract}
Glycosylation is one of the most important post-translational modifications of proteins, which affects biological activities by way of controlling higher order structure. Recently, the novel structure of glycoprotein, namely $C$-glycosyl protein was identified in various proteins. The first total synthesis of the naturally occurring $C$-glycosyl amino acid and peptide was achieved. The mannose and tryptophan moiety was connected via ring opening reaction of epoxide by lithiated indole derivative. After functional group conversion and deprotection, the glyco-amino acid was synthesized in a concise and stereoselective manner. To develop the rapid oligosaccharide construction methodology, the soluble polymer supported oligosaccharide was investigated. Due to high polarity of polymer support, the purification of PEG bound compound is achieved quite easily. The real-time monitoring of the glycosylation reaction was performed by MALDI-TOF MS, whereas the deprotection reaction of chloroacetyl group was performed by color test using ( $p$ nitrobenzyl) pyridine. The purification of PEG bound compound which has chloroacetyl group, is achieved by capturerelease strategy by use of resin bound cysteine derivative. By combination of these methodologies and novel linker, tetrasaccharides were synthesized.
\end{abstract}

Key words_— carbohydrate; polymer supported synthesis; linker; real-time reaction monitoring; capture-release purification

\section{はじめに}

糖鎖は，生体内で主に脂質やタンパク質と結合し てそれぞれ複合糖質と呼ばれる糖脂質, 糖夕ンパク 質として存在しており, 細胞間認識やシグナル伝達 に深く関わっている. ${ }^{1)}$ また, 細菌表層の細胞壁は peptideglycanからなっており, 抗生物質には細胞 壁の生合成を阻害する働きをするものも多い. ${ }^{2)}$ 夕 ンパク質は DNA の遺伝情報をもとに RNA 経て 生合成されるがそのままでは機能を発揮することが できず，リン酸化やジスルフィド結合の形成などの 翻訳後修飾を受けて成熟した形として発現し, また 機能の調節が行われることも多い. 糖鎖付加もタン パク質翻訳後修飾の 1 つの形態であるが，糖部分が 非常に嵩高いために, 分解酵素からタンパク質を保

理化学研究所 (T351-0198 和光市広沢 2-1)

e-mail: smanabe@postman.riken.go.jp

*本総説は, 平成 14 年度日本薬学会奨励賞の受賞を記 念して記述したものである。
護したり，アスパラギンターンを $\beta$-ターンに変え るなどペプチド主鎖のコンフォメーションに重要な 影響を及ぼす。3)

一方，低分子化合物においても抗生物質バンコマ イシンの糖鎖部を改変することにより耐性菌に対し ても活性をもつようにしたり, ${ }^{4)}$ エンジイン系抗生 物質の糖鎖部は DNA 配列の認識に重要な役割を果 たすことが示唆されている. ${ }^{5)}$ 細胞のガン化と細胞 表面糖鎖の認識の重要性は糖鎖一BSA コンジュ ゲートを用いてガンに対するワクチンを開発しよう とする試みが行われているに至っている。 ${ }^{6}$

「糖鎖生物学」は生命の根幹であるいわゆるセン トラルドグマから外れていることに加え, 糖鎖が生 体内で Glycoform と呼ばれる微細構造が少しずつ 違う一群の化合物として存在しているために, 単一 な化合物として得ることが非常に難しいこと, また 微量にしか存在しないことからこれまで困難がつき まとつてきたが, 今後の発展が期待される分野であ 
る. 有機合成化学は入手困難な化合物を純粋な形で 十分な量を供給するということにより貢献してき た. さらに天然に存在しない構造の化合物も供給可 能である．そのような見地から糖鎖合成についての 研究を行っているが, ここでは, 天然より見出され た $C$ - 結合型糖ペプチドの初の合成と糖鎖迅速合成 法についての新手法の開発について最近得られた知 見について述べる.

$\boldsymbol{C}$ - 結合型糖アミノ酸, 糖ペプチドの合成

さて, 糖タンパク質糖鎖部は大きく二つに分類さ れる.7)すなわち，アスパラギンの側鎖アミド基と 糖鎖部がアミド結合を介して結合している $N$ - 結合 型糖鎖とセリン又はスレオニンのヒドロキシル基と 糖鎖部が結合している $O$ - 結合型糖鎖である（Fig. 1).しかしながら, 1994 年ヒトRNaseよりマン ノースとトリプトファンが炭素結合を介して結合し た $C$ - 結合型糖アミノ酸 $\mathbf{1}$ が同定された（Fig. 2). $\left.{ }^{8}\right)$ その後, この $C$ - 結合型糖アミノ酸 $\mathbf{1}$ はヒトだけで はなく，海綿にも存在することが明らかになっ

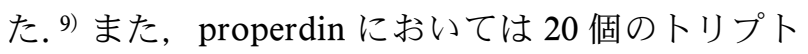
ファンの内, 実に 17 個がマンノースで修飾されて いることが見出され, 10)このタンパク質修飾の形は 当初考えられていたよりも普遍的に存在するのでは
ないかと考えられている，また，ペプチドにおける 認識部位は両末端にトリプトファンを含むテトラペ プチドであること11)や Dolichyl-phosphate-mannose が生合成経路においての前駆体であることも明らか になっている. ${ }^{12)}$

さて，この $C$ - マンノシルトリプトファン 1, 及 びそれを含むぺプチド 2 の合成を行うこととした. 生化学的プローブとなるように短行程であり, かつ 同位体導入や誘導体合成が容易になることを念頭に<smiles>[R7]N[C@H](Cc1c([C@@H]2O[C@H](CO)[C@@H](O)[C@H](O)[C@H]2O)[nH]c2ccccc12)C([R])=O</smiles>

$$
\begin{aligned}
& 1 R_{1}=H, R_{2}=O H \\
& 2 R_{1}=\text { Phe-Thr, } R_{2}=\text { Ala-Gin-Trp }
\end{aligned}
$$

Fig. 2. The Structure of $C$-Linked Glyco-Amino Acid and Glycopeptide
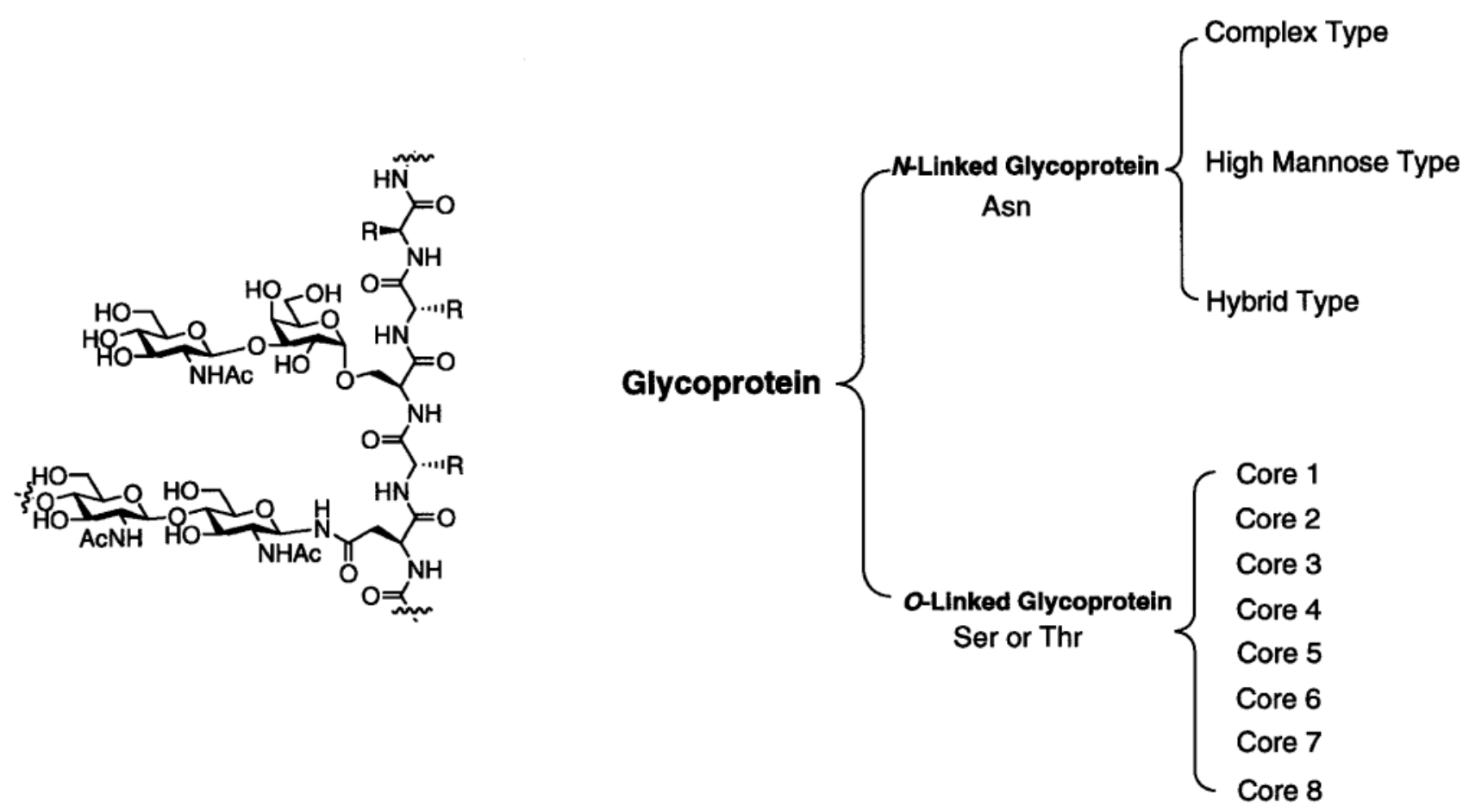

Fig. 1. $N$-Linked Glycoprotein and $O$-Linked Glycoprotein 


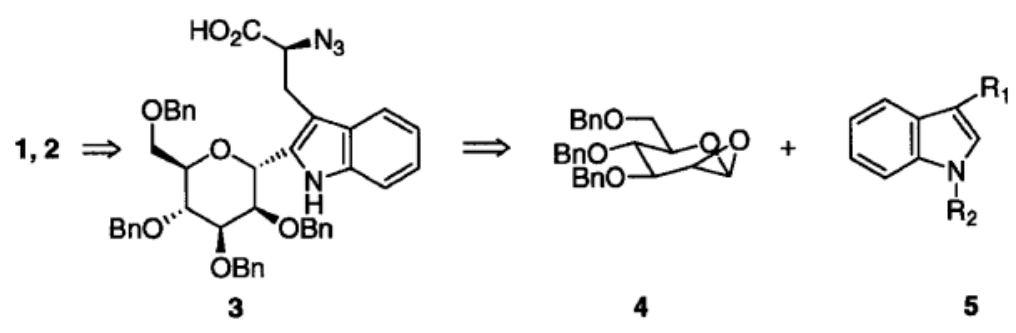

Scheme 1. The Retrosynthesis of $\mathbf{1}$ and $\mathbf{2}$

$\mathrm{R}_{1}=$ amino acid moiety precursor, $\mathrm{R}_{2}=$ protecting group.

おき，逆合成を行った．鍵となるのはマンノースと トリプトファンのインドール部分をどのように結合 させるか，またアミノ酸部分の不斉炭素をどのよう に構築するかということである、糖部分とアミノ酸 部分の結合はマンノースから 7 行程で誘導されるエ ポキシド 4 とインドール誘導体 $\mathbf{5}$ のメタロ体の反応 により合成できると考えられた（Scheme 1)。また さまざまなインドール誘導体を反応させることがで きるので誘導体合成にも有効であると思われる.さ て，エポキシドと有機金属化合物の反応は SN2 反 応で進行することが知られている. したがつてマン ノースのアノマー位においては望む立体配置である $\alpha$ 体のみが得られると期待された. しかしながら驚 いたことにエポキシド 4 とインドール誘導体 $\mathbf{5}$ のリ チオ体を $\mathrm{BF}_{3} \cdot \mathrm{OEt}_{2}$ 存在下反応させたところ, $\alpha$ 体と $\beta$ 体の混合物として付加体が得られた（Table 1).これはルイス酸である $\mathrm{BF}_{3} \cdot \mathrm{OEt}_{2}$ がエポキシ ドを活性化するとオキソカルベニウムイオン 8 が生 じて SN1 反応で反応が進行するためと説明できる (Scheme 2). また, 立体異性体の比はインドール 誘導体の構造に大きく依存することも明らかになつ た. すなわち, インドール窒素の保護基をベンゼン スルフォニル $\left(\mathrm{PhSO}_{2}\right)$ 基にするとインドール $\beta$ 位の置換基が大きくなるほど $\alpha$ 選択性が増大す る. 一方, Boc 基にかえると逆に $\beta$ 位の置換基が大 きくなるほど $\beta$ 選択性が増大する。 また， $\alpha$ 体は ${ }^{1} \mathrm{H}-\mathrm{NMR}$ において 1 位と 2 位とのカップリング定 数が $7.6 \mathrm{~Hz}$ であることと NOE が H-1 と H-5 に観 測されることから ${ }^{1} C_{4}$ コンフォメーションをとるこ とが明らかになった.これは $C$-グリコシドでは $O-$ グリコシドに見られるアノマー効果がないことやイ ンドールが嵩高いために equatorial 方向に配置する ためと考えられる. ${ }^{13)}$
Table 1. The Stereochemistry of the Reaction between 1,2Anhydro Mannose and Lithiated Indole Derivatives
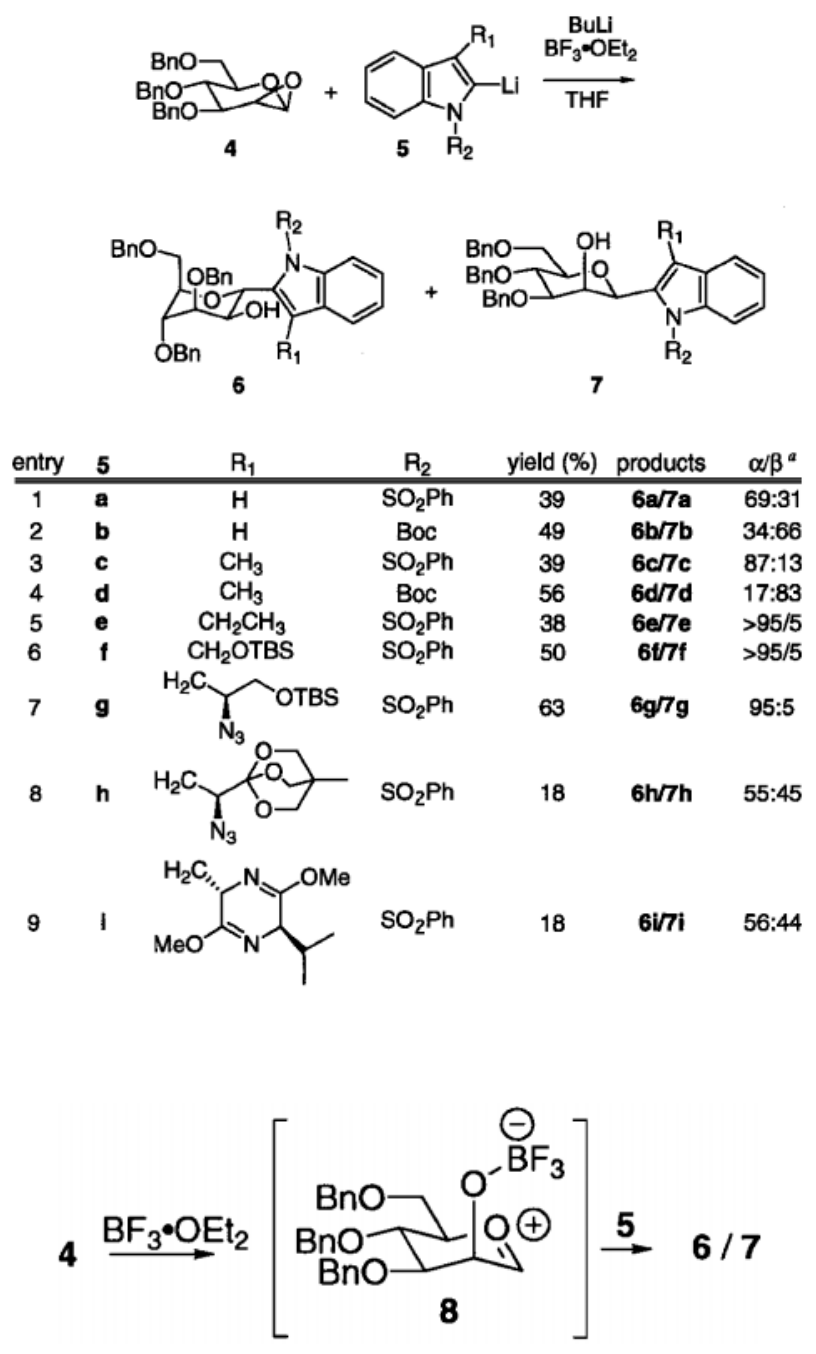

Scheme 2. The Oxocarbenium Intermediate

$\alpha$ 選択的に付加物を得るために以下のようにイン ドール誘導体をデザインした。すすおち，インドー ル窒素の保護基を $\mathrm{PhSO}_{2}$ 基とし, アミノ酸部の力 ルボン酸を一旦還元してアルコールのシリルエーテ 
ルとして保護することとした。この嵩高さは $\alpha$ 選 択性の発現に役立つ. $\mathrm{PhSO}_{2}$ 基はインドール窒素 を保護すると同時に $\alpha$ 位のリチ才化を促進し, ま た電子吸引基であるので側鎖水酸基をカルボン酸へ と戻す酸化反応の際，インドール環を酸化から保護 する働きを持つ、エポキシドとインドール誘導体の 付加反応は期待通り， $\alpha$ 選択的に生成物を与えた (Table 1, entry 7)。インドール側鎖にヘテロ環を含 む基質 $5 \mathbf{h}, 5 \mathbf{i}$ は付加体を 1 に導くことが可能であ るが，収率，選択性ともに低かった（Table 1, entry 8，9）。化合物 $6 \mathbf{g}$ の官能基変換後, 脱保護を行い, $C$ - マンノシルトリプトファン $\mathbf{1}$ の初の全合成に成 功した (Scheme 3). ${ }^{14)}$ 磯部らもアセチレン誘導体
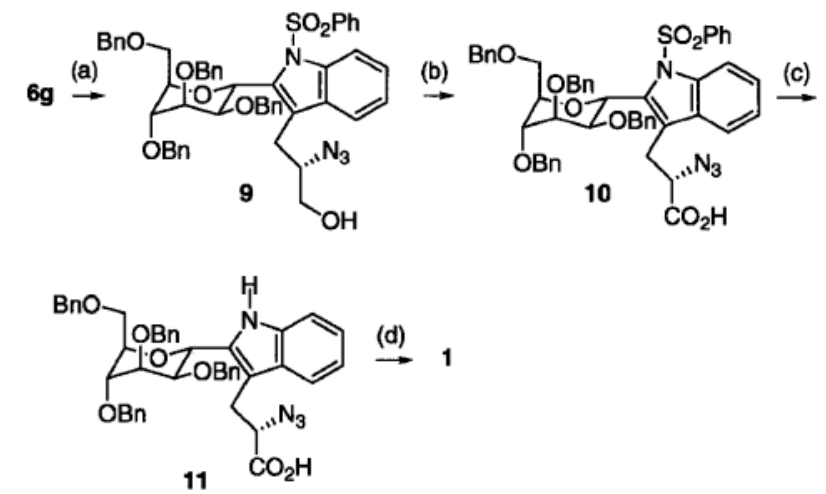

Scheme 3. Reagents and Yields: (a) (i) $\mathrm{BnBr}, n-\mathrm{Bu}_{4} \mathrm{NI}$, $\mathrm{NaH}, \mathrm{DMF}(92 \%)$, (ii) $\mathrm{TsOH} \cdot \mathrm{xH}_{2} \mathrm{O}, \mathrm{MeOH}(91 \%)$, (b) TEMPO, iodosobenzene diacetate, $\mathrm{CH}_{3} \mathrm{CN}, \mathrm{H}_{2} \mathrm{O}$ (97\%), (iii) $10 \% \mathrm{NaOH}, \mathrm{EtOH}, \mathrm{H}_{2} \mathrm{O}(78 \%)$, (c) $20 \% \mathrm{Pd}(\mathrm{OH})_{2} /$ C, $\mathrm{H}_{2}, \mathrm{EtOH}, \mathrm{THF}, \mathrm{H}_{2} \mathrm{O}(57 \%)$.
を $C$-グリコシル化した後，パラジウム触媒による インドール閉環，続くアミノ酸不斉炭素部導入によ る合成に成功している. $\left.{ }^{15}\right)$ 中間体 $\mathbf{1 0} の \mathrm{PhSO}_{2}$ 基を 脱保護して得られる 11 はペプチド合成のユニット としても有用である。すすおち，カルボキシル基 を in situ にて TFFH (tetramethylfluoroformidium hexafluorophosphate）により酸フッ化物としてア ミン 12 と反応させた.アジド基はペプチド結合形 成反応において隣接基関与しないため, ラセミ化し ないと期待される。 また，アジド基を trimethylphosphine により選択的に還元してアミノ基とし， さらにペプチドを伸長させることも可能であった (Scheme 4).

\section{糖鎖迅速合成に向けて}

1967 年 Merrifield がペプチド固相合成を開発し て以来, ${ }^{16)}$ さまざまな改良が施され，「だれにでも」 欲しいペプチドを合成できるようになったことは生 化学に非常に大きく貢献した。 その威力はペプチド 自動合成機, 核酸自動合成機が市販されるまでに至 つていることでも明らかであろう。ささ，核酸，ぺ プチドに続く「第 3 の生体内高分子」である糖鎖に ついても 1970 年代に固相合成法が検討された. ${ }^{17)}$ しかしながら, 当時は固相反応に適したグリコシル 化反応がなかったことなどから一般的手法として確 立するには至らなかった。しかし，1993 年 Danishefsky が彼ら独自に開発したグリカール法を 固相反応に応用したことにより, ${ }^{18)}$ 再び注目を集め

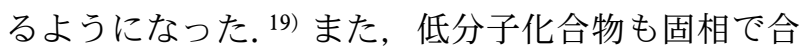
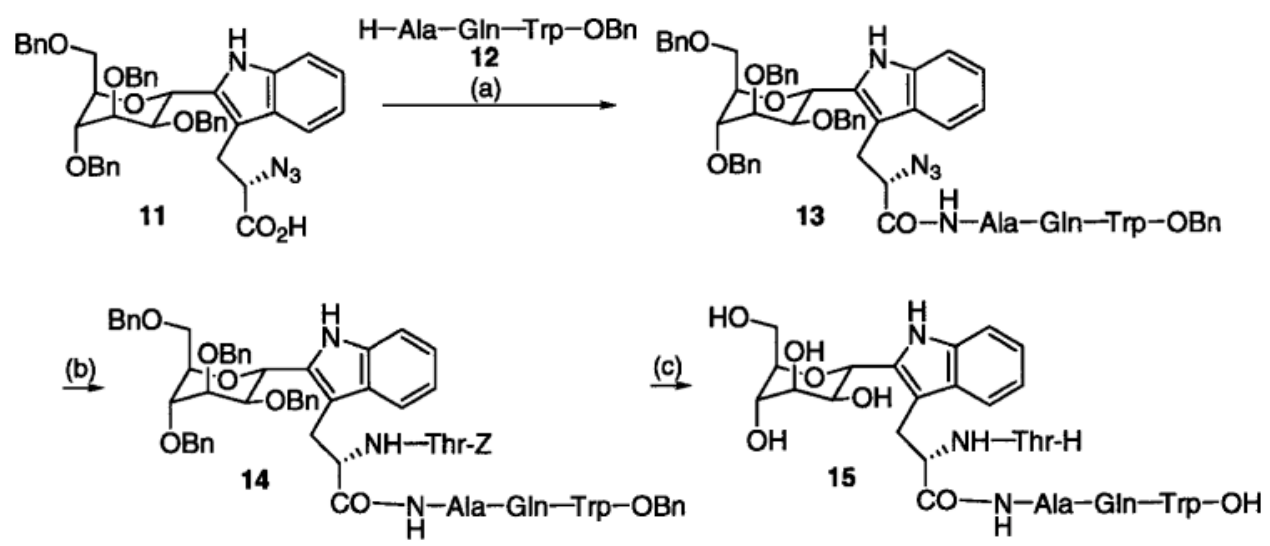

Scheme 4. Reagents and Yields: (a) TFFH, $\mathrm{Na}_{2} \mathrm{CO}_{3}, \mathrm{CH}_{2} \mathrm{Cl}_{2}, \mathrm{H}_{2} \mathrm{O}\left(76 \%\right.$ ), (b) i) $\mathrm{PMe}_{3}, \mathrm{THF}, \mathrm{H}_{2} \mathrm{O}$, ii) Fmoc-Thr-OH, WSCDI, HOBt, DMF (quant. 2 steps), iii) piperidine, DMF, iv) Z-Phe-OH, WSCDI, HOBt, DMF (76\%, 2 steps), (c) $20 \% \mathrm{Pd}(\mathrm{OH})_{2} / \mathrm{C}$, EtOH, THF, $\mathrm{H}_{2} \mathrm{O}$. WSCDI= water soluble carbodiimide; 1-ethyl-3-(3-dimethylaminopropyl)-carbodiimide $\cdot \mathrm{HCl}$. 
成することが近年盛んに行われている.これは固相 合成法が過剩の試薬を用いても固相樹脂をろ過, 洗 浄するだけで過剩の試薬を洗い流すことができる長 所があるため, 自動化のみならず, コンビナトリア ル・ケミストリーの基盤技術にもなる理由による.

近年盛んに研究が展開されている糖鎖固相合成で あるが，さまざまな問題点が存在していることも事 実である. 例えば, 固相での反応の追跡方法が開発 されていないこと, 固相反応では反応系が固一液の 不均一反応系となるために反応性が著しく低下する こと, 糖鎖固相合成に適したリンカーが開発されて いないことなどである，そこでこれらの問題点の解 決を目指した.

リンカーは非常に嵩高い固相と基質との距離を離 し, かつ最終物の固相からの切り出しを可能にする 固相反応に必要不可欠のものである. リンカーは最 終生成物に至るまでのすべての反応条件で安定でな ければならず，しかも最終生成物を損なうことなく 固相からの切り出しを行うことができなければなら ない. 糖鎖固相合成が酸性条件で行うグリコシル化 反応と塩基性条件で行う一時的な脱保護反応の繰り 返しとして成り立っていることを考えると, 糖鎖固 相合成でのリンカーは酸性条件でも塩基性条件にお いても安定で, かつ他の条件で切り出しが円滑に行 われなければならない.これまで固相反応はぺプチ ド合成を目的として発展してきた経緯があるために そのほとんどが酸性条件での切り出しを行うように 設計されている. しかしながら, 糖鎖合成に欠かせ ないグリコシル化反応はルイス酸条件で行うことが 多く, それらのリンカーの安定性に問題があること が知られていた．したがってグリコシル化反応の条 件設定に非常に制約を受けてしまう。そこで, Wang ( $p$-alkoxybenzyl) タイプのリンカーに非常 に強い電子吸引性基であるニトロ基を導入し, 酸に 対する安定性を増すこととした。事実, このリン カーは糖供与体としてイミデート, チオグリコシ ド, フッ化糖を用いる典型的グリコシル化反応の条 件で安定であることが示された。切り出しは Sn $(\mathrm{SPh})_{2}-\mathrm{PhSH}-\mathrm{Et}_{3} \mathrm{~N}$ を用いてニトロ基をヒドロキ シルアミンへと還元するとすみやかに環化反応が起 り, 最終物が液相へと放出される (Scheme 5)。こ のときに糖鎖合成で汎用されるアシル基, ベンジル 基，アセタール基，フタルイミド基は安定であるこ
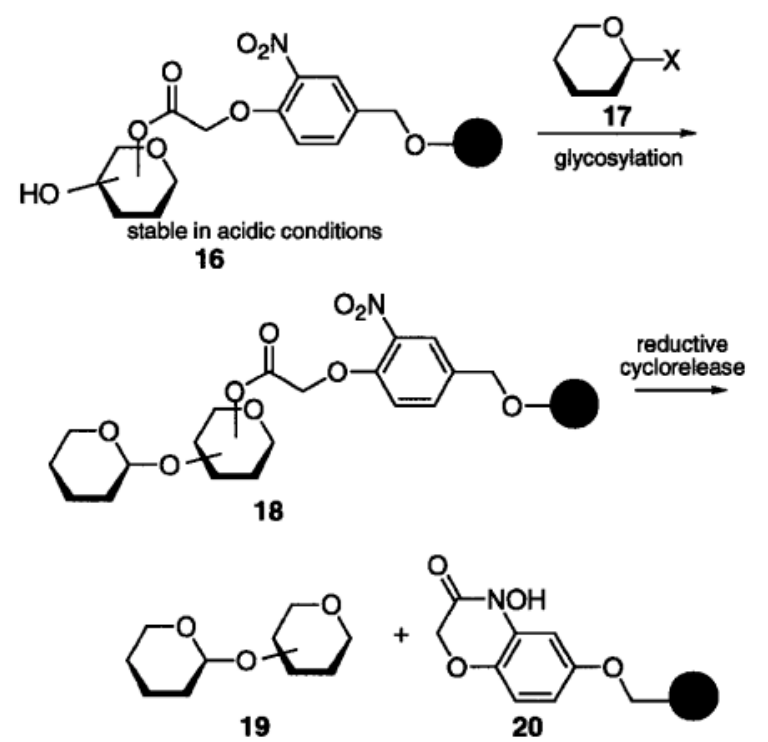

Scheme 5. The Novel Linker for Oligosaccharide Synthesis

とが分かった．すなわち，他のさまざまな保護基と 相補的に用いることが可能である. ${ }^{20)}$ また, 本リン カーは固相樹脂にもポリエチレングリコールなどの 高分子担体にも利用可能である. ${ }^{21)}$ また糖受容体, 糖供与体のいずれも固定化することができた.この リンカーを利用して $N$ - 結合型糖鎖の部分構造 $\mathbf{2 6}$ を合成することも可能であった（Scheme 6).

「タグ」としてのポリエチレングリコール

固相反応では固一液反応となるために反応性が著 しく低下する欠点がある．その欠点を克服するため に過剩の試薬や基質を用いているが, 固相上におい ても 99\%以上の収率で進行するようにさまざまな 検討が行われているペプチド結合形成反応と違って グリコシル化反応は液相においても 5 割から 9 割程 度でしか進行しないので反応性が著しく落ちる固相 反応においては過剩な基質を用いても反応を完結さ せることは非常に難しい。 そこで平均分子量 550 の ポリエチレングリコール（PEG）を高分子担体と して用いることとした. 短鎖 PEG はほとんどの溶 媒に可溶であるので均一性の反応系を与えるので, 反応性の高さを維持できる. また, 担持されている 化合物の構造や純度は通常の ${ }^{1} \mathrm{H}-\mathrm{NMR}$ で確認可能 である. また, 分子量が小さいのでそれ自身の分子 量が非常に大きい固相樹脂に比べ, スケールアップ も行える. さらに, 反応後, PEGの極性の高さを 利用して短いシリカゲルカラムクロマトグラフィー で精製できる.すなわち, 反応後, 反応液をシリカ 

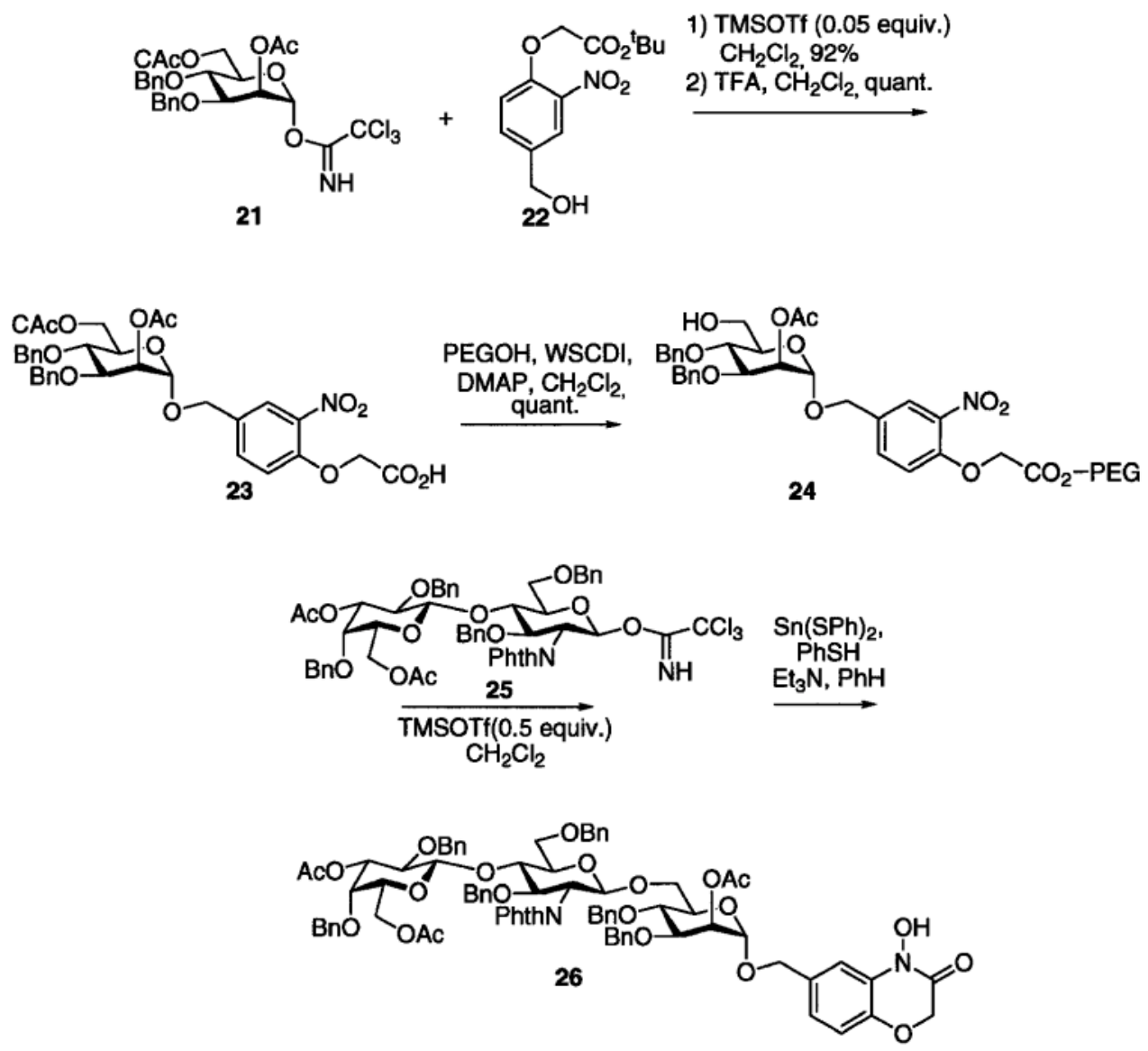

Scheme 6. $\mathrm{CAc}=$ chloroacetyl, $\mathrm{PEG}=$ poly (ethylene glycol) methyl ether (average M. W. 5000), TMSOTf=trimethylsilyl trifluoromethanesulfonate, WSCDI = water soluble carbodiimide, 1-ethyl-3-(3-dimethylaminopropyl) -carbodiimide $\cdot \mathrm{HCl}, \mathrm{Phth}=$ phthalimide.

ゲルカラムクロマトグラフィーに吸着させ，酶酸エ チルで溶出させると試薬などは溶出される.しかし, PEG に担持された化合物はその極性の高さから原 点に留まっている。ここで酢酸エチル一メタノール を流すとPEGが付いた化合物が溶出される.すな わち，極性の高さが PEG を「タグ」として働かせ

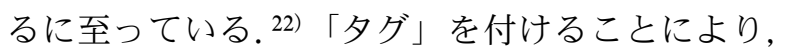
他の化合物との分離を容易にでき, しかも液相で反 応を行うことができるので反応性を低下させなくて すむ利点がある。最近, 低分子化合物の合成におい ても分離精製を簡便にするための種々の「タグ」が 開発されていることを付け加えておきたい. ${ }^{23)}$

\section{リアルタイムモニタリング法の開発}

さて，実験を進めるうちに PEG の極性の高さゆ えに反応の進行を TLC で追跡することが困難であ ることが分かった．これは固相反応や高分子担体上 での反応に共通する欠点である. 従来の液相反応に
おいては極少量の反応液をキャピラリーで取り出し て TLC などで解析し, 反応進行状況の確認や副生 成物の有無などの確認を行い, 反応条件にただちに フィードバックさせることができるが, 固相反応で はそのような技術がないために通常一旦固相から基 質を切り出して反応の解析を行わなければならない (Fig. 3). そのために反応条件の設定や反応条件最 適化には多大な時間を要することとなる。ペプチド 固相合成ではアミノ基の検出に用いられるニンヒド リン反応が反応追跡の手段として有名である. ${ }^{24)} し$ かしながら糖鎖合成における主要な官能基であるヒ ドロキシル基の固相上での検出法, 及び, 保護基の 検出法についてはほとんど確立されていない. Riguera らは固相上のヒドロキシル基 27 をトシル 化して脱離基へと変換した後，（ $p$-nitrobenzyl） pyridine 29 と反応させ, piperidine で処理して zwitterion 31 を発生させている。 この zwitterion 31 

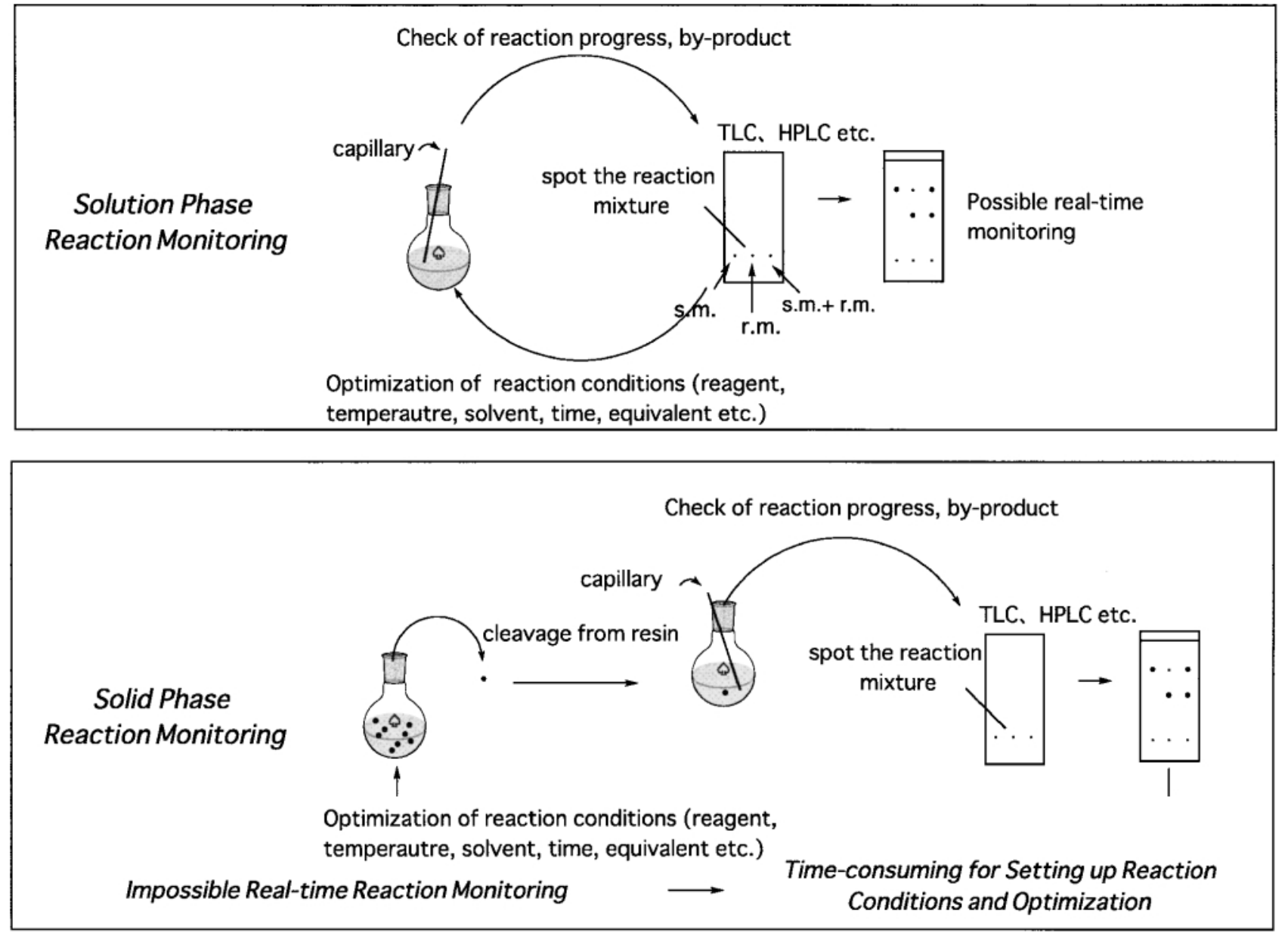

Fig. 3. Comparison of Reaction Monitoring between Solution Phase of Solid Phase

(a)

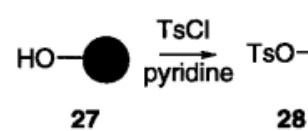

28<smiles>O=[N+]([O-])c1ccc(Cc2ccncc2)cc1</smiles>

27<smiles></smiles>

30<smiles></smiles>

31

(b)

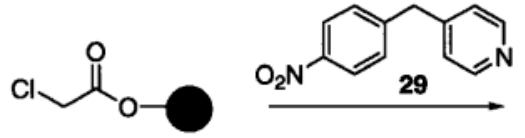

32<smiles>CCOC(=O)CC(=O)N1C=CC(Cc2ccc([N+](=O)[O-])cc2)=CC1</smiles>

33<smiles>CCCCOC(=O)C[n+]1ccc(C(=O)c2ccc([N+](=O)[O-])cc2)cc1</smiles>

34

Scheme 7. (a) The Detection Method of Hydroxy Group on Solid Phase Developed by Riguera, (b) The Detection Method of Chloroacetyl Group on Solid Phase

は，赤い色を示すことからヒドロキシル基の有無を

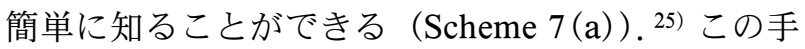
法を糖ヒドロキシル基に対して応用しようとしたと ころ, 恐らく低分子化合物のヒドロキシル基に比べ て糖のヒドロキシル基の反応性が低いことからうま
くいかなかった. そこでより反応性の高いと思われ るクロロアセチル（CAc）基 32 の塩素原子を脱離 基として利用することにした (Scheme 7 (b)). こ の反応を利用すると CAc 基の脱保護反応を固相あ るいは高分子担体から切り出すことなくモニターす 


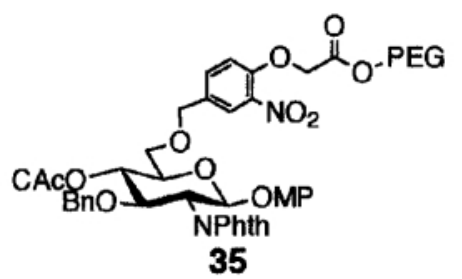

(a)

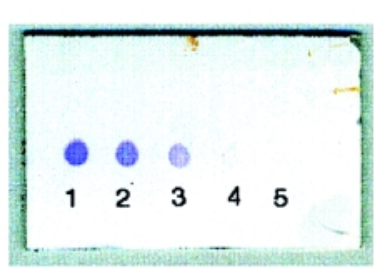

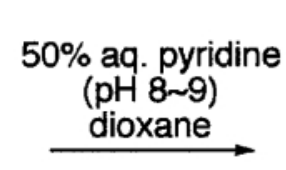

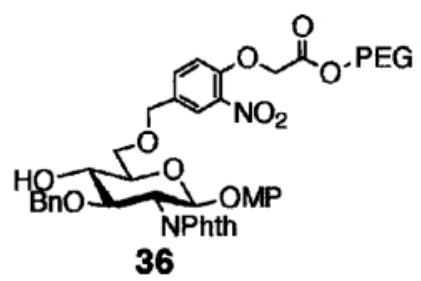

(b)

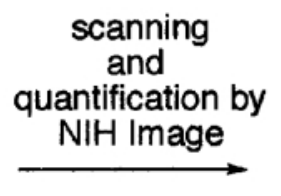

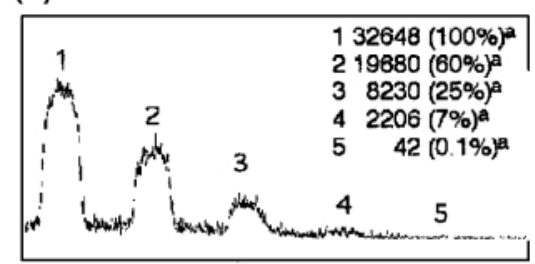

Fig. 4. Monitoring of Dechloroacetyl Group of $\mathbf{3 5}$ by Coloring with ( $p$-nitrobenzyl) Pyridine

(a) TLC profile (lane 1; $0 \mathrm{~h}$, lane 2; $0.5 \mathrm{~h}$, lane $3 ; 3 \mathrm{~h}$, lane 4; $3.5 \mathrm{~h}$, lane 5; $6 \mathrm{~h}$ ), (b) plot profile and density values analysed by NIH Image program (numbers are corresponding to theirs in $(a)) .{ }^{a)}$ Density percentage to that of lane 1 . MP $=p$-methoxyphenyl.

ることができる，可溶である PEG を担体としてク ロロアセチル基の脱保護をリアルタイムでモニター しながら行つた。すなわち，2 $\mu \mathrm{l}$ ずつ反応液を取り 出し, TLCにスポットし, ( $p$-nitrobenzyl) pyridine 溶液をスプレーして熱した後に piperidine 溶液 に浸した．呈色反応は時間が経過するごとに薄くな り, CAc 基の脱保護反応が進んでいることが示唆 された。この TLCをスキャナーでコンピュータに 画像として取り込み, 面積定量ソフトである NIHImage ${ }^{26)}$ で定量化することも可能であった。事実, ${ }^{1} \mathrm{H}-\mathrm{NMR}$ の積分值からの CAc 体と脱保護体の比と NIH-Image による積分值は比例関係があった（Fig. 4). 本方法は以下の特徵を持つ. CAc 基はいろい ろな条件, とくに塩基性条件で外れやすい保護基で あり, 固相や高分子担体から切り出す条件で脱保護 されてしまうこともあり, 切り出しての反応進行の 確認は難しいので, 固相樹脂, 高分子担体上での解 析は威力を発揮する。また, 糖鎖合成においては合 成最後まで使う“"permanent”な保護基（例えばべ ンジル基）と次にグリコシル化反応を行いたいヒド ロキシル基をグリコシル化反応のときだけ保護して おき, 次のグリコシル化反応の前には脱保護してし まう “tentative” な保護基（例えば CAc 基）が使 い分けられるが, CAc 基はこれまでの糖鎖合成で 一時的な保護基としての有用性が確立しているので それを含む糖ユニットの合成法などにこれまでの糖 化学の蓄積が固相合成法にも応用できると期待され る. また, 安価, 迅速, 選択的に CAc 基を選択で
きる利点を持つ. CAc 基が保護基として働くと同 時に潜在的クロモフォアとしても働いている訳であ る. 本方法を用いると単糖 35 の CAc 基の脱保護は 含水ピリジン中, 室温で 6 時間必要とするが, 4 糖 のクロロアセチル基の脱保護は 30 時間かかること もすぐに明らかになった．糖鎖固相合成のモニタリ ング法は実はいろいろと試みがなされている。 ${ }^{13} \mathrm{C}$ でラベル化したアセチル基を用いての gete

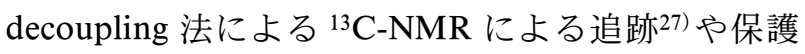
基にフッ素原子を用いて ${ }^{19} \mathrm{~F}-\mathrm{NMR}$ で追跡する方 法 ${ }^{28)}$ が開発されている.これらの方法は定量できる 長所がある反面, 反応を一旦止めてからでないと測 定できない欠点を持つ. 呈色反応を用いて固相反応 の追跡, 及び反応系の評価を行うことは糖鎖固相合 成でのみならず行われている，蛍光クロモフォアを 付けた基質を用いて Heck 反応の反応条件最適化を 行った例29)や光学分割を色素を用いて検討した 例 ${ }^{30)}$, 種々の官能基の有無を色素を用いて検出する 例 ${ }^{31)}$ が報告されている。 また，DNA マイクロアレ イを意識した「リアクションマイクロアレイ」も開 発されている. ${ }^{32)}$

さて, グリコシル化反応の追跡は短鎖 PEG の性 質を生かすことにした。すなわち, PEG は炭素鎖 長が正規分布している一群の化合物として販売され ているので, MALDI TOF MS (matrix assisted laser desorption ionization time of flight MS) のシグナル は正規分布の山のような特徵的な形状を示すことか ら他の化合物由来のシグナルと容易に区別ができる. 


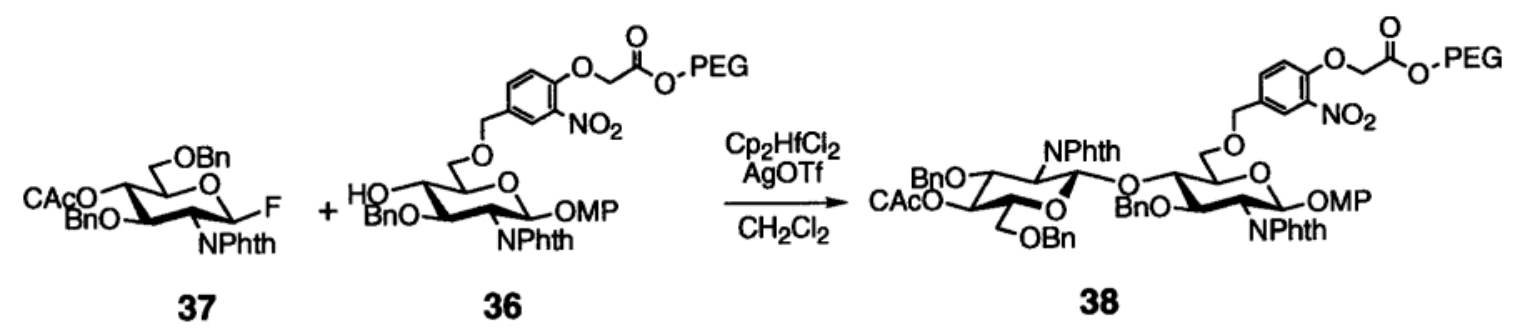

$\%$ Int.
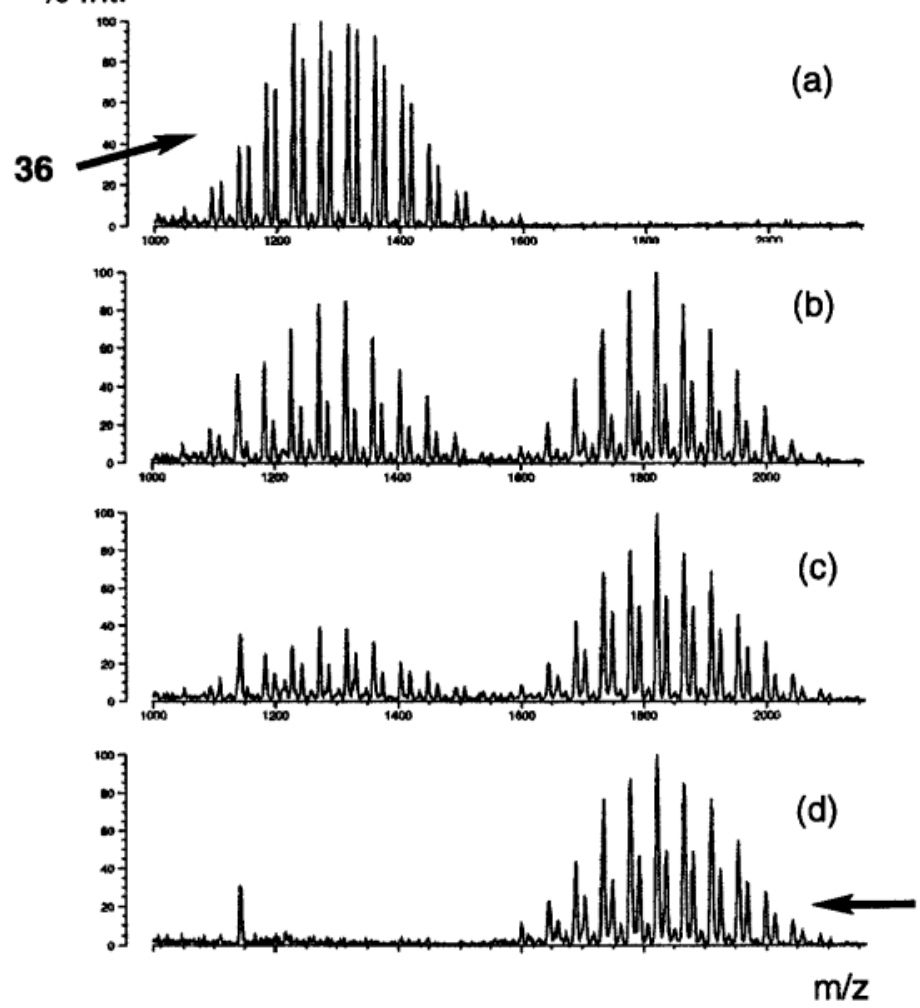

38

Fig. 5. MALDI-TOF MAS Spectra Showing the Course of Coupling Reaction of $\mathbf{3 6}$ and $\mathbf{3 7}$ (a) 0 min, (b) 1 min, (c) $3 \mathrm{~min}$, (d) $20 \mathrm{~min}$.

PEG に結合した糖受容体 $\mathbf{3 6}$ にフッ化糖 $\mathbf{3 7}$ を用い て $\mathrm{Cp}_{2} \mathrm{HfCl}_{2}-\mathrm{AgOTf}$ を活性化剂とする鈴木法によ りグリコシル化反応を行った. 反応が進むにつれて 山のようなシグナルは分子量が大きい方へと移動 し, 反応は 20 分で完結することが分かった (Fig. 5). 以上，糖鎖合成での基本反応であるグリコシル 化反応と脱保護反応のリアルタイムモニタリング法 を確立することができた。 PEGが精製を簡便にす る「タグ」として働いていると同時に反応モニタリ ングでも MS スペクトルにおいて特徵あるシグナ ルを示すことから“reporter”として働いている. 新規リンカーとリアルタイムモニタリング法を用い て PEG 上で迅速に 4 糖 39 を合成した. リンカー のニトロ基を還元することにより, PEGから切り
出しを行い, さらにリンカー由来のヒドロキサム酸 を含むべンジルエーテルを酸性条件で除去し, 高い 収率で化合物 $\mathbf{4 0}$ を得ることに成功した（Scheme 8). ${ }^{33)}$

高分子一固相樹脂ハイブリッド法による精製法の 開発

糖鎖合成の基本反応であるグリコシル化反応は液 相中においても収率は 50\%—90\%に留まっている ので, 反応性の低下する高分子担体上や固相樹脂上 ではさらに収率が低下する。いくら過剰の基質, 試 薬を用いても反応を完結させることは難しい. した がって何回かのグリコシル化反応を高分子上で行う と長さの違う糖鎖, 及びそれに由来する副生成物が 生成してしまい, 切り出し後の目的物の単離は困難 


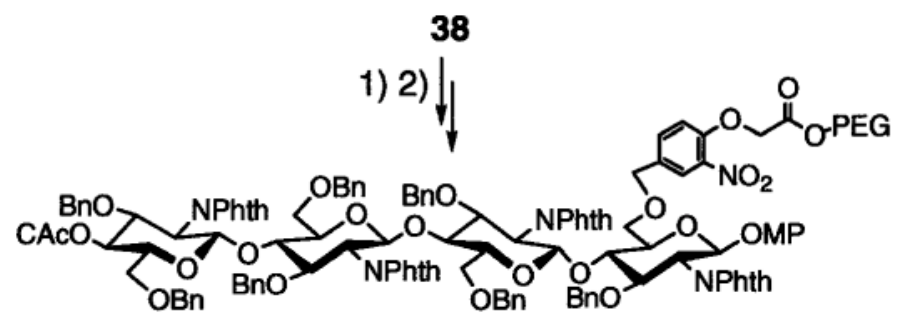

39

3)

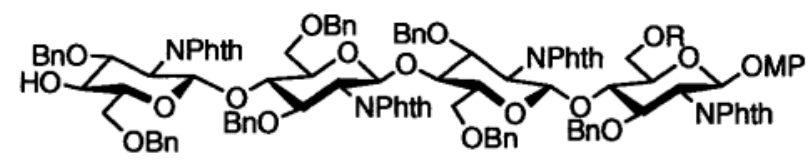

40

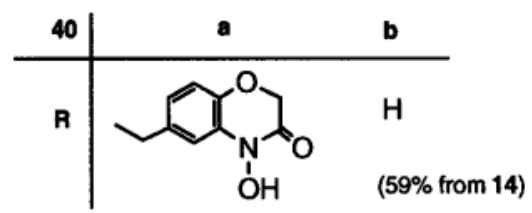

Scheme 8. Synthesis of Tetrasaccharide on PEG and Its Reductive Cyclo-Release

1) aq. Pyridine, 2) 37, $\left.\mathrm{Cp}_{2} \mathrm{HfCl}_{2}, \mathrm{AgOTf}, \mathrm{CH}_{2} \mathrm{Cl}_{2}, 3\right)$ i) aq. Pyridine, ii) $\mathrm{Sn}(\mathrm{SPh})_{2}, \mathrm{PhSH}, \mathrm{Et}_{3} \mathrm{~N}, \mathrm{PhH}$, iii) $\mathrm{CSA}, \mathrm{MeOH} .40: 74 \%$ yield from 39: $49 \%$ yield from 36 .

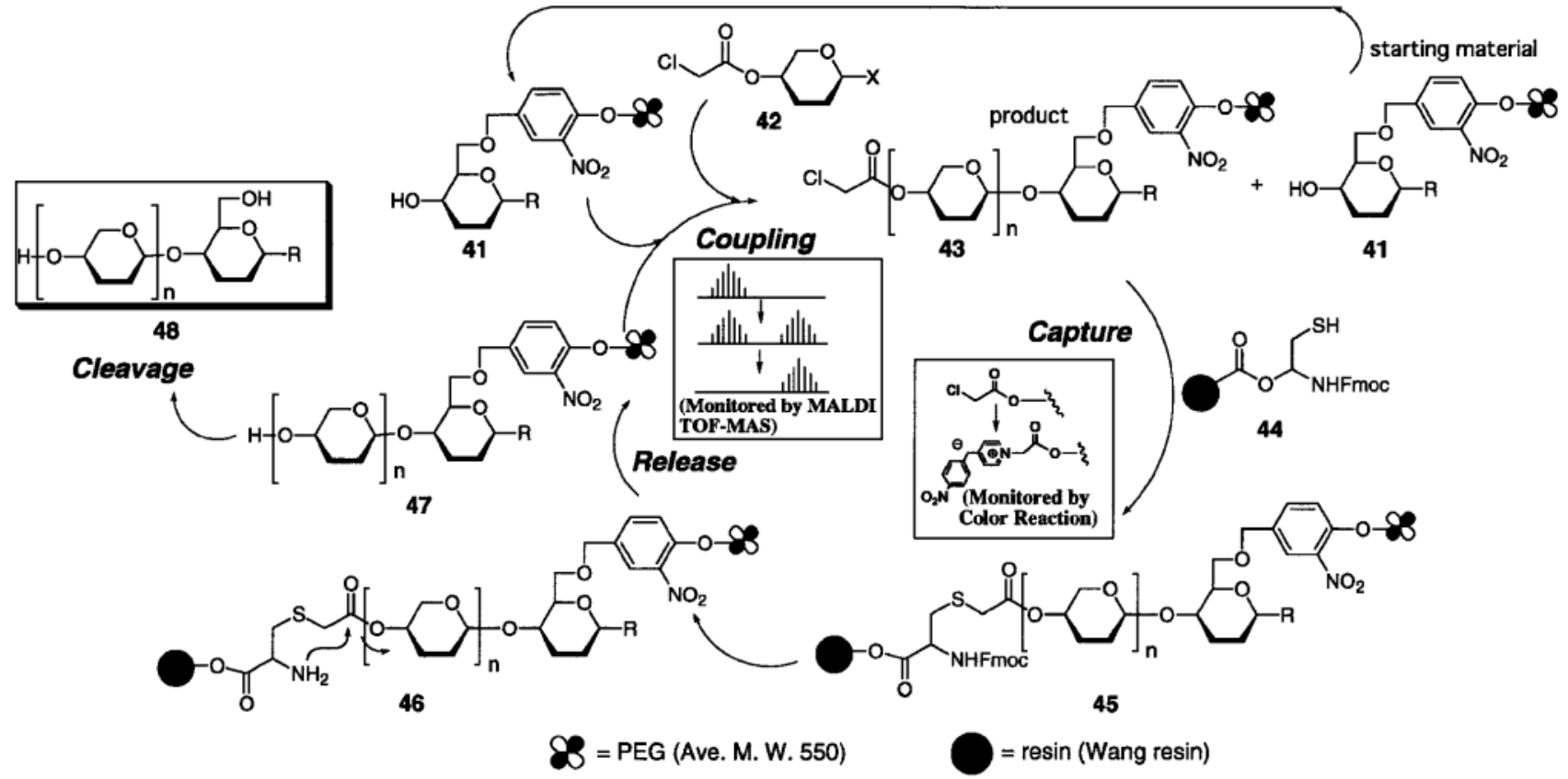

Fig. 6. The Cycle of Capture-Release Purification

を極めることとなる。一方で収率を高めるために多 大な条件検討を行うことは迅速合成の目的から外れ ることになる。これは液相での反応と違って反応終 了後の精製が高分子に基質が結合したままの状態で
できないことに起因する。 そこで CAc 基の反応性 を利用し，高分子担体に基質を結合させたまま精製 を行う手法を開発することとした。すなわち，CAc 基を持つ糖ユニット 42 を糖供与体として用いて 


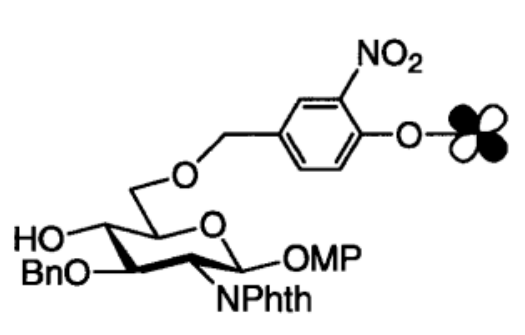

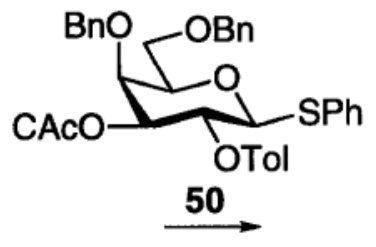

1)

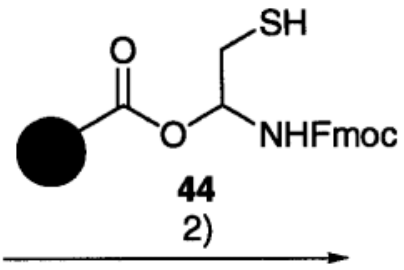

2)

49

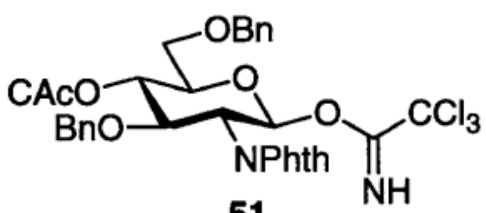

51

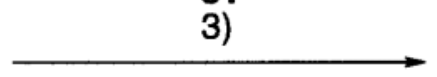

44, 2)

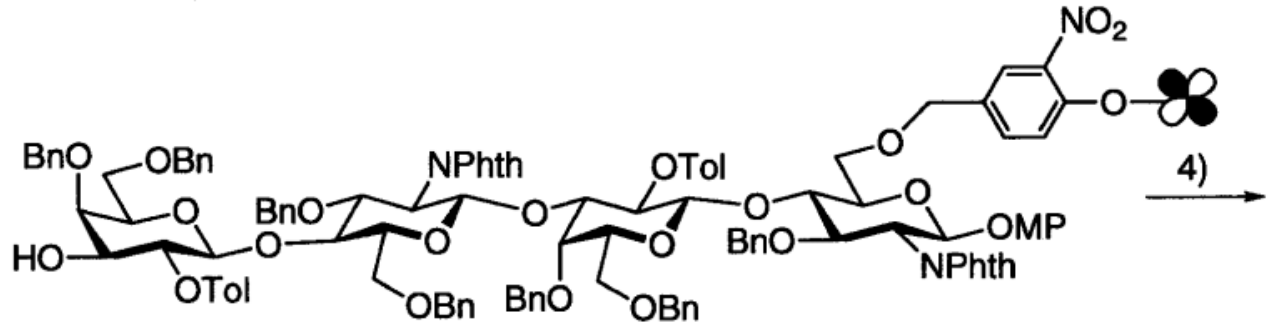

52

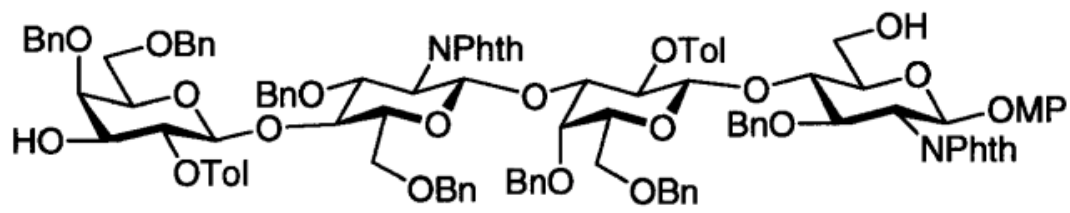

53

Scheme 9. The Synthesized Poly (Lactosamine) on PEG with Capture-Release Purification

1) DMTST ((Dimethylthio) methyl sulfonyl triflate), $\left.\mathrm{MS} 3 \mathrm{~A}, \mathrm{CH}_{2} \mathrm{Cl}_{2}, 2\right)$ i) $i-\mathrm{Pr}_{2} \mathrm{NEt}, \mathrm{CH}_{2} \mathrm{Cl}_{2}, \mathrm{CH}_{3} \mathrm{CN}$, ii) 4-(aminomethyl) piperidine, THF, 3) TMSOTf, $\mathrm{CH}_{2} \mathrm{Cl}_{2}$, 4) i) $\mathrm{Cu}-\mathrm{Zn}$, acetyacetone, $\mathrm{THF}$, ii) $\mathrm{Ac}_{2} \mathrm{O}, \mathrm{Et}_{3} \mathrm{~N}$, iii) $\mathrm{DDQ}$, dichloroethane, $\mathrm{H}_{2} \mathrm{O}$.

PEG 上の糖受容体 $\mathbf{4 1}$ と反応させると反応が完結し ない場合，原料である糖受容体 $\mathbf{4 1}$ と CAc 基を持つ 2 糖 43 が PEG 上に存在することになるが, PEG が非常に高い極性を持つためにこの 2 つ化合物は シリカゲルカラムクロマトグラフィーでは分離する ことができない，そこで PEG 成分のみをシリカゲ ルカラムクロマトグラフィーで分離した後, 固相樹 脂に担持されたシステイン誘導体 $\mathbf{4 4}$ を加えた。す ると固相樹脂に担持されたシステインのチオール基 と CAc 基の塩素原子は置換反応を起こし, CAc 基
を持つもののみが固相樹脂上へ「つりあげ（Capture)」られる。「つりあげ」の反応は CAc 基を検 出する（p-nitrobenzyl）pyridine 法で追跡し, 終了 を知ることができる。一方，ヒドロキシル基である 未反応の糖受容体 41 は反応しないので, 固相樹脂 をろ過, 洗浄することにより洗い流すことができ る.すなわち, この段階でシリカゲルカラムクロマ トグラフィーで分離できない高分子上の複数の化合 物の分離が固相樹脂を用いることにより可能になつ た. 次にアミノ基の保護基を脱保護するとすみやか 
に環化反応により 2 糖 $\mathbf{4 7}$ は高分子担体ごと液相へ と放出（Release）される。この一連の反応は CAc 基の脱保護反応にもなっており，次のグリコシル化 反応の糖受容体として使用可能である (Fig. 6). ${ }^{1} \mathrm{H}-\mathrm{NMR}$ により PEG に結合している化合物の純度 が上っていることが確められた。この方法を利用し て精製を行いながら，自然界に広く存在するポリラ クトサミン 4 糖 $\mathbf{5 3}$ を合成することに成功した (Scheme 9). ${ }^{34)}$

おわりに

糖鎖研究はポストゲノム時代の科学的興味のター ゲットの 1 つとなることであろう. 固相合成法は担 持された基質の単離がろ過, 洗浄でよいので簡便で あることが強調されるが，一方，反応性が著しく低 下するのを克服するために過剰の試薬を用いるの で，例えば 1 級水酸基と 2 級水酸基の区別など選択 的な反応条件を設定するには困難がつきまとうなど の欠点がある. しかしながら最近, 固相樹脂自身や 反応装置にもさまざまな改良が加えられたり, 固相 樹脂上の化合物の構造解析の手法も開発され，さま ざまな展開支援がはかられている。それにつれて天 然物, 及び類縁体の固相合成も行われているが, 固 相合成の上で複雑な骨格を持つ化合物を多段階を要 して合成することは，溶媒による固相樹脂の膨潤な ども考慮に入れた綿密な合成計画のみならず，新し い概念や手法が必要となることであろう。また糖鎖 は他の生体内高分子であるペプチドや核酸と違って 枝別れ構造を持つという特徵があり, 純粋化学合成 のためには相補的な条件で保護, 脱保護ができる保 護基の開発，より高い収率を与え，アノマー位の立 体化学を完璧に制御し得るグリコシル化反応の開発 など根本的解決に向けての努力もなされなければな らない. 今後, 自動化, コンビナトリアル・ケミス トリーに向けてのさらなる展開を行いたいと思って いる.

謝辞理化学研究所伊藤幸成主任研究員には御 指導, 御助言を賜りました。ここに厚く感謝いたし ます，共同研究者の方々にも御礼申し上げます。併 せて財政的援助を頂いた科学技術振興事業団 (CREST)，新エネルギー産業技術総合開発機構, 理化学研究所理事長ファンド, 薬学奨励財団, 文部 科学省に感謝いたします。

\section{REFERENCES}

1) a) Varki A., Glycobiology, 3, 97-130 (1993);

b) Dwek R.A., Chem. Rev., 96, 683-720 (1996).

2) a) Bugg T. D. H., Compr. Nat. Prod. Chem., 3, 241-294 (1999); b) Goldman R. C., Gange D., Curr. Med. Chem., 7, 801-820 (2000).

3) O'Connor S. E., Imperiali B., Chem. Biol., 5, 427- 437 (1998).

4) Ge M., Chen Z., Onishi H. R., Kohler J., Silver L. L., Kerns R., Fukuzawa S., Thompson C., Kahne D., Science, 284, 507-511 (1999).

5) a) Nicolaou K. C., Smith B. M., Pastor J., Watanabe Y., Weinstein D. S., Synlett, 1997, 401-410; b) Sissi C., Aiyar J., Boyer S., Depew K., Danishefsky S., Crothers D. M., Proc. Nat. Acad. Sci. U.S.A., 96, 1064310648 (1999).

6) a) Kudryashov V., Glunz P. W., Williams L. J., Hintermann S., Danishefsky S. J., Lloyd K. O., Proc. Nat. Acad. Sci., 98, 3264-3269 (2001) ; b) Gilewski T., Ragupathi G., Bhuta S., Williams, L. J., Musselli C., Zhang X-F., Bencsath K. P., Panageas K. S., Chin J., Hudis C. A., Norton L., Houghton A. N., Livingston P. O., Danishefsky S. J., Proc. Nat. Acad. Sci., 98, 3270-3275 (2001).

7) Kobata A., Acc. Chem. Res., 26, 319-324 (1993).

8) Hofsteenge J., Müller D. R., de Beer T., Löffler A., Richter W. J., Vliegenthart J. F. G., Biochemistry, 33, 13524-13530 (1994).

9) Garcia A., Lenis L. A., Jiménez C., Debitus C., Quinoá E., Riguera R., Org. Lett., 2, 2765 -2767 (2000).

10) Hartmann S., Hofsteenge J., J. Biol. Chem., 275, 28569-28574 (2000).

11) Krieg J., Hartmann S., Vicentini A., Gläsner W., Hess D., Hofsteenge J., Mol. Bio. Cell., 9, 301-309 (1998) .

12) Doucey M.-A., Hess D., Cacan R., Hofsteenge J., Mol. Bio. Cell., 9, 291-300 (1998).

13) Manabe S., Ito Y., Ogawa T., Chem Lett., 919 -920 (1998).

14) Manabe S., Ito Y., J. Am. Chem. Soc., 121, 9754-9755 (1999).

15) Nishikawa T., Ishikawa M., Wada K., Isobe 
M., Synlett, 2001, 945-947.

16) Merrifield B., J. Am. Chem. Soc., 85, 21492152 (1963).

17) Frechet J. M. J., Schuerch C., J. Am. Chem. Soc., 93, 492-496 (1971).

18) Danishefsky S. J., McClure K. F., Randolph J. T., Ruggeri R. B., Science, 260, 1307-1309 (1993).

19) a) Ito Y., Manabe S., Curr. Opin. Chem. Biol., 2, 701-708 (1998); b) Seeberger P. H., Haase W. C., Chem. Rev., 100, 4349-4393 (2000).

20) Manabe S., Nakahara Y., Ito Y., Synlett., 2000, 1241-1244.

21) Manabe S., Ito Y., Chem. Pharm. Bull., 49, 1234-1235 (2001).

22) Jiang L., Hartly C., Chan T.-H., Chem. Commun., 1996, 2193-2194.

23) a) Pozgay V., Org. Lett., 1, 477-480 (1999); b) Perrier H., Labelle M., J. Org. Chem., 64, 2110-2113 (1999) ; c) Zhang S.-Q., Fukase K., Kusumoto S., Tetrahedron Lett., 40, 74797483 (1999); d) Itami K., Mitsudo K., Kamei T., Koike T., Nokami T., Yoshida J., J. Am. Chem. Soc., 122, 12013-12014 (2000); e) Ley S. V., Massi A., Rodríguez F., Horwell D. C., Lewthwaite R. A., Pritchard M. C., Reid A. M., Angew. Chem. Int. Ed., 40, 1053-1055 (2001).

24) Kaiser E., Colescott R. L., Bossinger C. D., Cook P. I. Anal. Biochem., 34, 595-598
(1970) .

25) Kuisle O., Lolo M., Quinoá E., Riguera R., Tetrahedron, 55, 14807-15812 (1999).

26) http://rsb.info.nih.gov/nih-image/

27) Kanemitsu T., Kanie O., Wong C-H., Angew. Chem. Int. Ed., 37, 3415-3418 (1998).

28) Mogemark M., Elofsson M., Kihlberg J., Org. Lett., 3, 1463-1466 (2001).

29) Shaughnessy K. H., Kim P., Hartwig J. F., J. Am. Chem. Soc., 121, 2123-2132 (1999).

30) Weingarten M. D., Sekanina K., Still W. C., J. Am. Chem. Soc., 120, 9112-9113 (1998).

31) a) Attardi M. E., Falchi A., Taddei M., Tetrahedron Lett., 41, 7395-7399 (2000); b) Madder A., Farcy N., Hosten N. G. C., De Muynck H., De Clercq P. J., Barry J., Davis A. P., Eur. J. Org. Chem., 2787-2791 (1999); c) Burkett B. A., Brown R. C. D., Meloni M. M., Tetrahedron Lett., 42, 5773-5775 (2001); d) Badyal J. P., Cameron A. M., Cameron N. R., Coe D. M., Cox R., Davis B. G., Oates L. J., Oye G., Steel P. G., Tetrahedron Lett., 42, 8531-8533 (2001).

32) Korbel G. A., Lalic G., Shair M. D., J. Am. Chem. Soc., 123, 361-362 (2001).

33) Ando H., Manabe S., Nakahara Y., Ito Y., $J$. Am. Chem. Soc., 123, 3848-3849 (2001).

34) Ando H., Manabe S., Nakahara Y., Ito Y., Angew. Chem. Int. Ed., 40, 4725-4728 (2001). 